\title{
Ecosystem response more than climate variability drives the inter-annual variability of carbon fluxes in three Chinese grasslands
}

\author{
Tao Zhang a,b,c,d, Yangjian Zhang a,c,*, Mingjie Xu ${ }^{\mathrm{a}, \mathrm{b}}, \mathrm{Yi} \mathrm{Xi}^{\mathrm{a}}{ }^{\mathrm{a}, \mathrm{c}, \mathrm{d}}$, Juntao Zhu ${ }^{\mathrm{a}, \mathrm{c}}$, \\ Xianzhou Zhang ${ }^{\mathrm{a}, \mathrm{c}}$, Yanfen Wang ${ }^{\mathrm{d}}$, Yingnian $\mathrm{Li}^{\mathrm{e}}$, Peili Shi ${ }^{\mathrm{a}}$, Guirui $\mathrm{Yu}^{\mathrm{a}}{ }^{\mathrm{a}}$, Xiaomin Sun ${ }^{\mathrm{a}}$ \\ a Key Laboratory of Ecosystem Network Observation and Modeling, Institute of Geographic Sciences and Natural Resources Research, Chinese Academy of \\ Sciences, Beijing 100101, China \\ b College of Agronomy, Shenyang Agricultural University, Shenyang 110866, China \\ ${ }^{c}$ Center for Excellence in Tibetan Plateau Earth Sciences, Chinese Academy of Sciences, Beijing 100101, China \\ d University of Chinese Academy of Sciences, Beijing 100049, China \\ e Northwest Institute of Plateau Biology, Chinese Academy of Sciences, Xining 810001, China
}

\section{A R T I C L E I N F O}

\section{Article history:}

Received 24 October 2014

Received in revised form 2 May 2016

Accepted 6 May 2016

Available online 20 May 2016

\section{Keywords:}

Ecosystem response

Carbon flux

Inter-annual variability

Driving force

Grassland

\begin{abstract}
A B S T R A C T
The inter-annual variability (IAV) of net ecosystem productivity (NEP) may be caused by both climatic factors and ecosystem responses. In this study, we used eddy covariance (EC) measurements over three typical grasslands in China to investigate the dynamics of NEP and its two components - gross primary productivity (GPP) and ecosystem respiration (Re) and their driving forces. We found that climatic factors and ecosystem response simultaneously influence the IAV of ecosystem carbon fluxes, with a dominant effect arising from an ecosystem response. On a daily scale, carbon fluxes were driven primarily by climatic factors, but effects from an ecosystem response strengthened when the period of analysis was extended. On an annual scale, ecosystem responses weakened the effects of climatic variability on ecosystem carbon fluxes for the three grasslands. This negative feedback demonstrated that ecosystem acclimatization to climate variability can constrain the IAV of carbon fluxes induced by such variability.
\end{abstract}

(c) 2016 Elsevier B.V. All rights reserved.

\section{Introduction}

Carbon flux of grassland ecosystems normally exhibits higher sensitivities to climatic perturbations than do forest ecosystems (Novick et al., 2004; Flanagan et al., 2002; Gilmanov et al., 2007; Polley et al., 2010). This leads to greater uncertainty in estimating grassland carbon budgets. More thorough knowledge about how environmental and biological factors drive carbon flux variability and related mechanisms is critical to account for their present status and predict their future status. In addition, the longer the time scale, the more complex the driving mechanisms become. To date, our knowledge on the aforementioned aspects is still severely limited (Hui et al., 2003).

A number of factors interact to influence the variability of carbon fluxes and make separating their respective effects difficult (Hui et al., 2003). Moreover, such effects are dynamic across mul-

\footnotetext{
* Corresponding author at: Institute of Geographic Sciences and Natural Resources Research, Chinese Academy of Sciences, Beijing 100101, China.

E-mail address: zhangyj@igsnrr.ac.cn (Y. Zhang).
}

tiple spatial and temporal scales (Stoy et al., 2009). These factors include temperature, precipitation, radiation and other climatic factors (Griffis et al., 2000); interrelated physiological and ecological processes (Botta et al., 2000; Griffis et al., 2000); and a dynamic balance between photosynthesis and respiration (Potter et al., 2001; Schimel et al., 2001). According to their sources, the drivers of carbon flux can generally be divided into two categories (Marcolla et al., 2011; Wu et al., 2012): abiotic (climate) and biotic (ecosystem responses).

Previous studies have focused mainly on direct impacts of climatic factors, while neglecting effects of ecosystem responses (Xu and Baldocchi, 2004; Zhang et al., 2011; Wu et al., 2012). However, effects of ecosystem responses are in fact persistent phenomena. Fire affects ecosystem structure and generates spatial heterogeneity across a landscape (Goetz et al., 2007). Nitrogen deposition causes changes in plant species composition and ecosystem productivity (Berendse et al., 2001; Stevens et al., 2004). Defoliation can transfer stress signals to interspecific neighbors through ectomycorrhizal networks to facilitate ecosystem recovery and succession after disturbance (Song et al., 2015). All these disturbances and management practices are expected to weaken the 
relationship between carbon fluxes and climatic variables, resulting in a larger contribution of ecosystem responses (Shao et al., 2013; Shao et al., 2015; Zhang et al., 2015b). In certain situations, ecosystem responses might exert an even greater influence on carbon fluxes than those generated by climate (Hollinger et al., 2004; Richardson et al., 2007; Desai et al., 2010; Marcolla et al., 2011). Especially for studies conducted on temporal scales longer than one year, effects of ecosystem responses require more adequate attention (Katul et al., 2001). For example, high spring temperatures were found to enhance photosynthesis in the following autumn (Richardson et al., 2009). Favorable climate may promote plant growth in a given year, but in subsequent years plant growth might decrease due to tradeoff effects between plant and microbial activities (Braswell et al., 1997).

Parametric models are commonly used in studying carbon flux patterns (Griffis and Rouse, 2001; Katul et al., 2001; Richardson et al., 2007; Stoy et al., 2009) and their relationships to climatic variability. However, these models are invariably constrained in being biased toward effects of environmental drivers (Gunderson et al., 2010), while neglecting effects of ecosystem responses. Water stress can amplify the effects of ecosystem responses (Granier et al., 2007; Hao et al., 2008). As a result, the accuracy of VPM models that fail to include ecosystem responses decreases under conditions of severe drought (Wu et al., 2008). In addition, ecosystem responses may act as a buffer and result in lagged effects of climatic factors on ecosystem carbon fluxes (Braswell et al., 1997; Teklemariam et al., 2010). Such lagged effects induced by temperature on $\mathrm{CO}_{2} \mathrm{can}$ last for several months, even half a year (Zhang et al., 2015a), yet these effects are often neglected by parametric models. Therefore, ecosystem response effects must be taken into account to improve the accuracy of parametric models.

To date, few studies have been reported in quantifying ecosystem responses (Hui et al., 2003; Richardson et al., 2007; Polley et al., 2010; Marcolla et al., 2011; Wu et al., 2012) or on the relative contribution of climatic factors and ecosystem responses to carbon fluxes (Xu et al., 2014), especially for grassland systems. To address the aforementioned issues, we chose three typical grassland ecosystems in China and used their nearly-continuous eddy-covariance flux data to: (1) characterize the IAV of carbon fluxes; and (2) separate the sources of IAV into climate effects and ecosystem responses.

\section{Data and methodology}

\subsection{Site description}

Measurements were conducted across three grassland ecosystems located on the Qinghai-Tibet Plateau and Inner Mongolia Plateau, which represent two typical grasslands in China. The three grassland ecosystems include an alpine Kobresia pygmaea meadowsteppe ecosystem with an alpine monsoon climate at Dangxiong site (DX) located in the hinterland of the Qinghai-Tibet Plateau; an alpine Potentilla fruticosa shrub-meadow ecosystem with a continental monsoon climate at Haibei site (HB) located on the northeast edge of the Qinghai-Tibet Plateau; and a temperate Leymus chinensis steppe ecosystem with a continental semi-arid climate at Neimeng site (NM) located in the Xilin River Basin in Inner Mongolia (Table 1). Detailed descriptions of these study sites may be found in Li et al. (2003) for HB, Shi et al. (2006) for DX, and Fu et al. (2006b) and Hao et al. (2006) for NM.

\subsection{Measurements and data processing}

Eddy covariance carbon fluxes at the three sites were measured at a height of $2.5 \mathrm{~m}$ with standard systems, including an open-path
EC infrared $\mathrm{CO}_{2} / \mathrm{H}_{2} \mathrm{O}$ analyzer (Model LI-7500, Li-cor Inc., Nebraska, USA) and a three-dimensional sonic anemometer (Model CSAT3, Campbell Scientific Inc., Logan, Utah, USA). All raw data were sampled with a frequency of $10 \mathrm{~Hz}$ and then recorded at 30-min intervals by a CR5000 datalogger (Model CR5000, Campbell Scientific). Micrometeorological conditions, including air temperature (Ta), net radiation ( $\mathrm{Rn})$, precipitation (PPT) and soil volumetric water content at a depth of $5 \mathrm{~cm}(\mathrm{SWC})$ were measured at $1 \mathrm{~Hz}$, then averaged for half-hour intervals.

We utilized Matlab7.11 software (MathWorks Inc., Natick, MA, USA) to process flux data. A three-dimension rotation was used to align the coordinate system with mean wind direction (Falge et al., 2001; Wilczak et al., 2001). Then we applied the WPL correction - the Webb, Pearman and Leuning density correction for effects of air density fluctuations-to adjust air density changes caused by heat and water vapor fluctuations (Webb et al., 1980). Anomalous or spurious values caused by sensor malfunction and interference from rain, dew, hoarfrost, and birds, etc. were excluded from our analysis. The eddy covariance technique is likely to underestimate nighttime $\mathrm{CO}_{2}$ fluxes due to low-atmospheric turbulence under stable conditions (Reichstein et al., 2005). We excluded night observations (solar elevation angle $<0$ ) when the friction velocity $\left(\mathrm{u}^{*}\right)$ was under the thresholds as determined by plotting nighttime $\mathrm{CO}_{2}$ fluxes to friction velocity at each site (Reichstein et al., 2005). The thresholds were identified as $0.15 \mathrm{~m} \mathrm{~s}^{-1}$ for DX and HB and $0.2 \mathrm{~m} \mathrm{~s}^{-1}$ for NM, respectively. We did not consider self-heating as it only occurred in winter for the open-path eddy covariance system. Winter temperature is extremely low in our study area and carbon fluxes in winter only account for a small proportion of the annual fluxes, thus contributing little to the inter-annual variation of annual carbon fluxes (Burba et al., 2008; Reverter et al., 2011; Zhu et al., 2012). Linear and nonlinear fittings and mean diurnal variations were adopted to fill missing and spurious data (Fu et al., 2006a). Finally, we aggregated 30-min-average flux data to daily, monthly and annual sums.

\subsection{Partitioning the sources of the inter-annual variability of carbon flux}

The IAV of ecosystem carbon fluxes can be ascribed to two main sources-climate and ecosystem responses. We used a look up table (LUTs) method to separate the respective effects of climate and ecosystem responses (Marcolla et al., 2011; Xu et al., 2014). In the process, the key was to build LUTs for each individual year and data averaged over multiple years. The two types of LUTs can be used to extract the individual effects of climate or ecosystem responses from their strongly coupled interactions.

Among the set of climate factors potentially regulating carbon fluxes, hydrothermal conditions play a primary role (Piao et al., 2008; Barron-Gafford et al., 2012; Parton et al., 2012). Thus for climate data, we included only temperature and soil water content. To create the LUTs, we merged 30-min-average temperature, soil water content and carbon flux data (NEP, GPP, Re) to a daily sum for each year. We integrated these daily sums into one table, the daily data table (DD, Table S1).

(1) Generating the LUTs for Variable Climate and Variable Ecosystem Response (VC_VER). We classified the flux data into each range of temperature $\left(\mathrm{Ta}\right.$, per $0.2^{\circ} \mathrm{C}$ ) and soil water content (SWC, per $0.03 \mathrm{~m}^{3} \mathrm{~m}^{-3}$ ) for each year using DD. Within each climatic data range, each carbon flux component (NEP, GPP, $\mathrm{Re}$ ) might have several daily values, and we took their separate averages. This enabled the generation of a second table of data comprised of a series of climate data ranges and their corresponding carbon fluxes, this table being referred to as the annual LUT (ANN_LUT, Table S2). We used the daily climate 
Table 1

Site information for the three focal grasslands (DX, HB and NM) in China.

\begin{tabular}{|c|c|c|c|}
\hline Site & DX & HB & NM \\
\hline $\begin{array}{l}\text { Observation } \\
\text { period }\end{array}$ & 2004-2011 & 2003-2008 & 2004-2008 \\
\hline Location & $30^{\circ} 51^{\prime} \mathrm{N}, 91^{\circ} 05^{\prime} \mathrm{E}$ & $37^{\circ} 40^{\prime} \mathrm{N}, 101^{\circ} 20^{\prime} \mathrm{E}$ & $43^{\circ} 33^{\prime} \mathrm{N}, 116^{\circ} 40^{\prime} \mathrm{E}$ \\
\hline Elevation (m) & 4333 & 3293 & 1252 \\
\hline $\begin{array}{l}\text { Mean } \\
\text { precipitation } \\
(\mathrm{mm})\end{array}$ & 480 & 580 & 350 \\
\hline $\begin{array}{l}\text { Mean } \\
\text { temperature } \\
\left({ }^{\circ} \mathrm{C}\right)\end{array}$ & 1.3 & -2 & -0.4 \\
\hline Ecosystem type & Alpine meadow-steppe & $\begin{array}{l}\text { Alpine } \\
\text { shrub-meadow }\end{array}$ & Temperate steppe \\
\hline $\begin{array}{l}\text { Dominant } \\
\text { species }\end{array}$ & $\begin{array}{l}\text { Stipa capillacea, } \\
\text { Carex montis, } \\
\text { Kobresia pygmaea }\end{array}$ & $\begin{array}{l}\text { Potentilla fruticosa, } \\
\text { Kobresia capillifolia, } \\
\text { Kobresia humilis }\end{array}$ & $\begin{array}{l}\text { Leymus chinesis, } \\
\text { Stipa grandis, } \\
\text { Agropyron } \\
\text { cristatum }\end{array}$ \\
\hline $\begin{array}{l}\text { Vegetation } \\
\text { coverage (\%) }\end{array}$ & 40 & 75 & $\sim 100$ \\
\hline $\begin{array}{l}\text { Canopy height } \\
(\mathrm{cm})\end{array}$ & 10 & 55 & 45 \\
\hline $\begin{array}{l}\text { Maximum LAI } \\
\left(\mathrm{m}^{2} \mathrm{~m}^{-2}\right)\end{array}$ & 1.0 & 2.8 & 1.5 \\
\hline Soil type & Sandy loam & Silty clay loam & Medium loam \\
\hline
\end{tabular}

data (Ta and SWC) in DD (Variable Climate, VC) to look up the ANN_LUT (Variable Ecosystem Response, VER) and reproduced carbon fluxes for each day of each year. The variations in carbon fluxes calculated by this approach could be assumed to be caused both by climatic factors and the ecosystem responses. We defined these looked-up results as VC_VER, which should be equal to the observed values.

(2) Generating the LUTs for Variable Climate and Constant Ecosystem Response (VC_CER). We built a multiple year average table (MYA, Table S3) by calculating multiple year averages for daily climatic variables and carbon fluxes for each day (from DOY 1 to 366) of every year during the study period. For example, we obtained for MYA DOY 3 temperature at DX by calculating averages of DOY 3 temperature for every year from 2004 to 2011. We classified the flux data into each temperature range ( $\mathrm{Ta}$, per $0.2^{\circ} \mathrm{C}$ ) and soil water content (SWC, per $0.03 \mathrm{~m}^{3} \mathrm{~m}^{-3}$ ) using the MYA data. A fourth table was then generated (MYA_LUT, Table S4), which was also comprised of a series of climate ranges and their corresponding MYA carbon fluxes. We used the daily climate data (Ta and SWC) for each day of each year in DD (Variable Climate, VC) to look up the MYA_LUT (Constant Ecosystem Response, CER) and reproduced carbon fluxes for each day of every year. We defined these looked-up results as VC_CER. By this approach, we were able to exclude effects of ecosystem responses and reflect only the climate effects.

(3) Generating the LUTs for Constant Climate and Variable Ecosystem Response (CC_VER). We used the MYA climate data (Constant Climate, CC) to look up the ANN_LUT (Variable Ecosystem Response, VER) year by year, and then reproduced carbon fluxes for each day of each year. With this approach we were able to exclude effects of climate and reflect only the effects of ecosystem responses. We defined these looked-up results as CC_VER.

The standard deviations of the annual carbon fluxes obtained from the three approaches (VC_VER, VC_CER and CC_VER) were used to estimate the IAV generated from different sources. Then we analyzed the interactions between climate drivers and ecosystem responses.
Table 2

The annual dynamics of main climatic factors over the three sites. The observation period is 2004-2011 at DX, 2003-2008 at HB and 2004-2008 at NM; AVG represents climatic factors averaged over the observation period, CV means coefficient of variation.

\begin{tabular}{llllll}
\hline & & Ta $\left({ }^{\circ} \mathrm{C}\right)$ & $\mathrm{Rn}\left(\mathrm{MJ} \mathrm{m}^{-2}\right)$ & $\mathrm{PPT}(\mathrm{mm})$ & $\mathrm{SWC}\left(\mathrm{m}^{-3} \mathrm{~m}^{-3}\right)$ \\
\hline \multirow{2}{*}{$\mathrm{DX}$} & AVG & 2.81 & 2016.88 & 415.91 & 0.099 \\
& IAV & 0.74 & 102.18 & 146.93 & 0.021 \\
& CV & 0.26 & 0.05 & 0.35 & 0.21 \\
$\mathrm{HB}$ & AVG & -1.53 & 2880.03 & 473.90 & 0.209 \\
& IAV & 0.37 & 94.58 & 65.45 & 0.014 \\
& CV & 0.24 & 0.03 & 0.14 & 0.07 \\
NM & AVG & 1.64 & 2066.46 & 252.46 & 0.085 \\
& IAV & 0.54 & 150.67 & 89.25 & 0.012 \\
& CV & 0.33 & 0.07 & 0.35 & 0.15
\end{tabular}

\section{Results and discussion}

3.1. The annual dynamics of environmental conditions and $\mathrm{CO}_{2}$ fluxes

Different environmental conditions were observed across the three sites (Table 2). Mean annual temperature (Ta) was highest at DX; while the HB site had higher radiation (Rn), precipitation (PPT) and soil water content (SWC) than at both DX and NM. The PPT and SWC were lowest at NM. The inter-annual variation of Rn was lower than that of other climatic factors. The inter-annual variation of climatic factors at HB was smaller than that at the other two sites.

The seasonal dynamic curves of cumulative carbon fluxes were similar among the three sites (Fig. 1). The cumulative carbon fluxes (NEP, GPP and Re) increased quickly during the growing season, and then decreased gradually (NEP) or leveled off (GPP and Re) along with vegetation senescence.

The IAV of carbon fluxes is reflected in the error bars. The IAV of NEP was the largest at DX (Fig. 1(d)), followed by that at NM (Fig. 1(f)), and then HB (Fig. 1(e)). A similar trend was exhibited for the IAV of GPP and Re (Fig. 1(j-l), (p-r)).

The difference of the standard deviation (DStDev) of NEP at HB and NM abruptly increased during the onset of the growing season, then rapidly decreased during growing seasons (Fig. 1(e and f)), which is in line with other similar studies (Wohlfahrt et al., 2008a; Marcolla et al., 2011). The DStDev at DX suddenly decreased in May following low NEP in April of 2010 (Fig. 1(a)). The peak DStDev in 


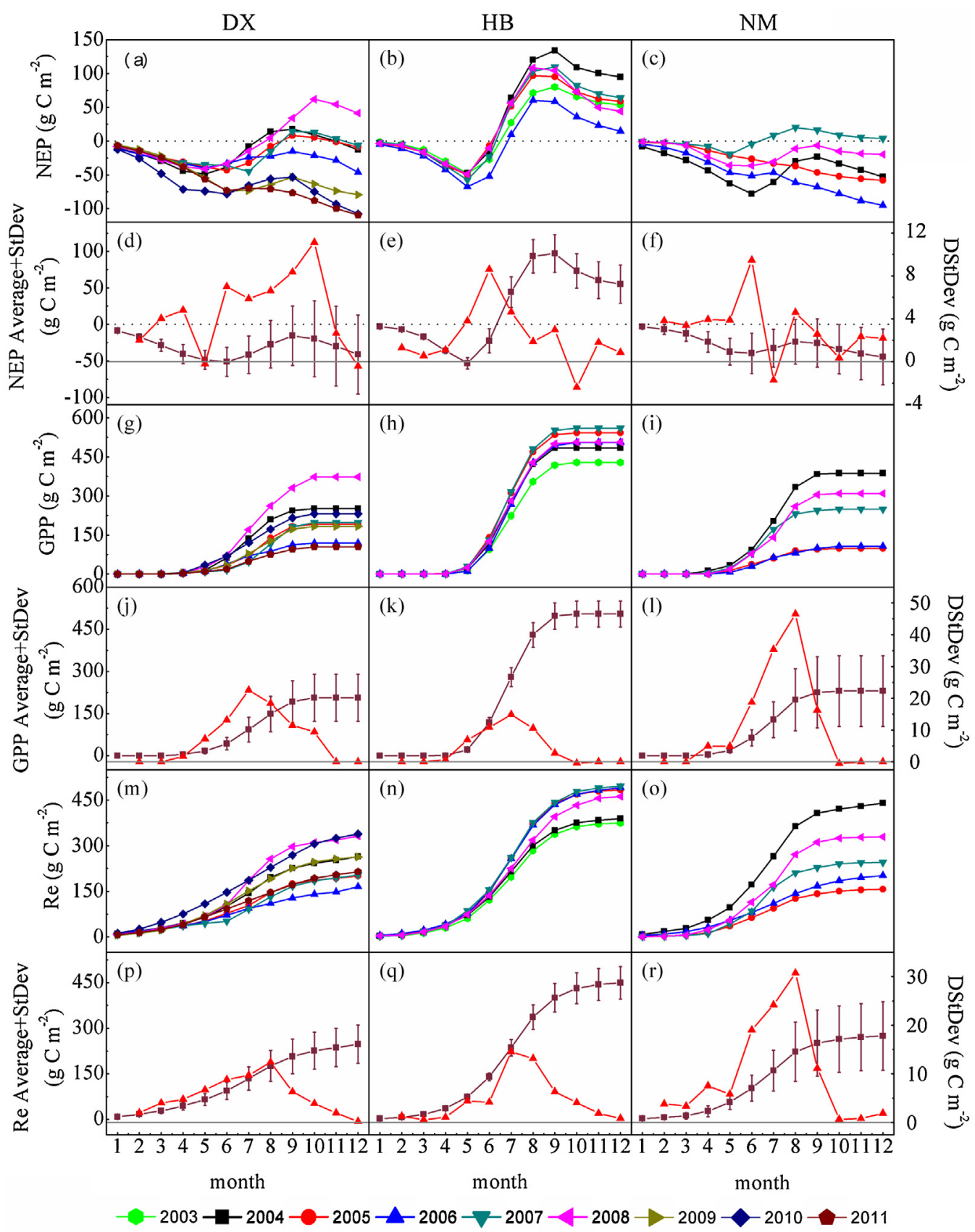

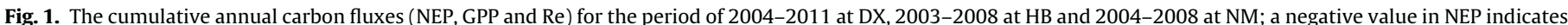

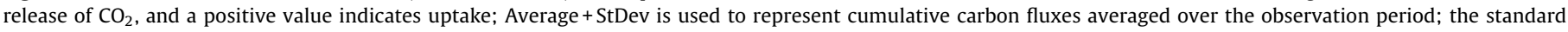
deviation and the monthly difference in standard deviations (DStDev) quantify the contributions of each month to the observed IAV.

October occurred simultaneously with significantly higher GPP in 2008 (Fig. 1(a and g)).

The DStDev curves of GPP and Re exhibited a unimodal pattern at the three sites (Fig. 1(j-1), (p-r)), with a maximum value during the peak growing season (July-August); while that of NEP occurred during the onset of growing seasons (June). The differentiated timing of the peak IAV revealed a dominant climatic effect on GPP and Re in the growing season (Hollinger et al., 2004), and their offset advanced the maximum IAV of NEP to an earlier date (Potter et al., 2001; Schimel et al., 2001). The DStDev of GPP and Re were almost consistently positive during the whole year. Among the three focal sites, the DStDev in growing season at NM was much greater than those at DX and HB, which may be related to a wider inter-annual climate variation at NM. The constraining effects from precipita- tion were more severe at NM under relatively higher temperature conditions. Consequently, climate contributed to a higher DStDev. In addition, the more severe precipitation constraint can lead to wider ecosystem response variations in such aspects as biomass (Zhang et al., 2015b), photosynthetic capacity and species composition (Misson et al., 2010; Rustad et al., 2001; Xu et al., 2014).

Ecosystem carbon fluxes are driven by climatic variability (Suyker et al., 2003; Xu and Baldocchi, 2004; Wen et al., 2006; Zhang et al., 2011), but other factors must be accounted for over a long time scale (Barford et al., 2001; Stoy et al., 2009). The correlations between carbon fluxes and climatic factors abated with time (Table 3). Specifically, the correlations were strongest on a daily scale, followed by those on a monthly scale. At an annual scale, the correlations were not significant. As the effects 
Table 3

The correlation analysis between carbon fluxes and climatic factors along with the extension of time scale over the three sites.

\begin{tabular}{|c|c|c|c|c|c|c|c|c|c|c|c|c|c|c|}
\hline & \multirow[b]{2}{*}{ Time scale } & \multicolumn{5}{|c|}{$\mathrm{DX}$} & \multicolumn{4}{|l|}{ HB } & \multicolumn{4}{|l|}{ NM } \\
\hline & & & $\begin{array}{l}\text { Ta } \\
\left({ }^{\circ} \mathrm{C}\right)\end{array}$ & $\begin{array}{l}\mathrm{Rn} \\
\left(\mathrm{MJ} \mathrm{m}^{-2}\right)\end{array}$ & $\begin{array}{l}\text { PPT } \\
(\mathrm{mm})\end{array}$ & $\begin{array}{l}\text { SWC } \\
\left(\mathrm{m}^{-3} \mathrm{~m}^{-3}\right)\end{array}$ & $\begin{array}{l}\text { Ta } \\
\left({ }^{\circ} \mathrm{C}\right)\end{array}$ & $\begin{array}{l}\mathrm{Rn} \\
\left(\mathrm{MJ} \mathrm{m}^{-2}\right)\end{array}$ & $\begin{array}{l}\text { PPT } \\
(\mathrm{mm})\end{array}$ & $\begin{array}{l}\text { SWC } \\
\left(\mathrm{m}^{-3} \mathrm{~m}^{-3}\right)\end{array}$ & $\begin{array}{l}\text { Ta } \\
\left({ }^{\circ} \mathrm{C}\right)\end{array}$ & $\begin{array}{l}\mathrm{Rn} \\
\left(\mathrm{MJ} \mathrm{m} \mathrm{m}^{-2}\right)\end{array}$ & $\begin{array}{l}\text { PPT } \\
(\mathrm{mm})\end{array}$ & $\begin{array}{l}\text { SWC } \\
\left(\mathrm{m}^{-3} \mathrm{~m}^{-3}\right)\end{array}$ \\
\hline \multirow[t]{6}{*}{ NEP } & \multirow[t]{2}{*}{ daily } & $r$ & 0.43 & 0.44 & 0.36 & 0.67 & 0.46 & 0.47 & 0.08 & 0.15 & 0.12 & 0.14 & -0.07 & 0.11 \\
\hline & & $\mathrm{P}$ & $<0.01$ & $<0.01$ & $<0.01$ & $<0.01$ & $<0.01$ & $<0.01$ & $<0.01$ & $<0.01$ & $<0.01$ & $<0.01$ & $<0.01$ & $<0.01$ \\
\hline & \multirow[t]{2}{*}{ monthly } & $r$ & 0.52 & 0.56 & 0.67 & 0.76 & 0.58 & 0.49 & 0.72 & 0.21 & 0.21 & 0.19 & 0.51 & 0.48 \\
\hline & & $\mathrm{P}$ & $<0.01$ & $<0.01$ & $<0.01$ & $<0.01$ & $<0.01$ & $<0.01$ & $<0.01$ & 0.08 & 0.10 & 0.15 & $<0.01$ & $<0.01$ \\
\hline & \multirow[t]{2}{*}{ yearly } & $\mathrm{r}$ & -0.53 & 0.45 & 0.73 & 0.65 & -0.93 & -0.52 & 0.12 & -0.69 & 0.52 & 0.06 & -0.12 & -0.63 \\
\hline & & $\mathrm{P}$ & 0.17 & 0.26 & 0.04 & 0.08 & 0.01 & 0.29 & 0.82 & 0.13 & 0.37 & 0.93 & 0.85 & 0.25 \\
\hline \multirow[t]{6}{*}{ GPP } & \multirow[t]{2}{*}{ daily } & $r$ & 0.67 & 0.67 & 0.38 & 0.72 & 0.74 & 0.61 & 0.23 & 0.43 & 0.57 & 0.56 & 0.16 & 0.39 \\
\hline & & $\mathrm{P}$ & $<0.01$ & $<0.01$ & $<0.01$ & $<0.01$ & $<0.01$ & $<0.01$ & $<0.01$ & $<0.01$ & $<0.01$ & $<0.01$ & $<0.01$ & $<0.01$ \\
\hline & \multirow[t]{2}{*}{ monthly } & $r$ & 0.73 & 0.75 & 0.81 & 0.77 & 0.80 & 0.68 & 0.86 & 0.48 & 0.66 & 0.66 & 0.87 & 0.41 \\
\hline & & $\mathrm{P}$ & $<0.01$ & $<0.01$ & $<0.01$ & $<0.01$ & $<0.01$ & $<0.01$ & $<0.01$ & $<0.01$ & $<0.01$ & $<0.01$ & $<0.01$ & $<0.01$ \\
\hline & \multirow[t]{2}{*}{ yearly } & $r$ & -0.13 & 0.64 & 0.66 & 0.43 & -0.21 & -0.25 & -0.31 & 0.69 & 0.66 & 0.63 & 0.76 & 0.21 \\
\hline & & $\mathrm{P}$ & 0.76 & 0.09 & 0.08 & 0.28 & 0.69 & 0.64 & 0.55 & 0.13 & 0.23 & 0.25 & 0.14 & 0.73 \\
\hline \multirow[t]{6}{*}{$\operatorname{Re}$} & \multirow[t]{2}{*}{ daily } & $r$ & 0.67 & 0.67 & 0.28 & 0.55 & 0.86 & 0.63 & 0.33 & 0.60 & 0.63 & 0.62 & 0.22 & 0.47 \\
\hline & & $\mathrm{P}$ & $<0.01$ & $<0.01$ & $<0.01$ & $<0.01$ & $<0.01$ & $<0.01$ & $<0.01$ & $<0.01$ & $<0.01$ & $<0.01$ & $<0.01$ & $<0.01$ \\
\hline & \multirow[t]{2}{*}{ monthly } & $r$ & 0.75 & 0.75 & 0.76 & 0.63 & 0.90 & 0.76 & 0.89 & 0.66 & 0.74 & 0.75 & 0.90 & 0.48 \\
\hline & & $\mathrm{P}$ & $<0.01$ & $<0.01$ & $<0.01$ & $<0.01$ & $<0.01$ & $<0.01$ & $<0.01$ & $<0.01$ & $<0.01$ & $<0.01$ & $<0.01$ & $<0.01$ \\
\hline & \multirow[t]{2}{*}{ yearly } & $r$ & 0.28 & 0.47 & 0.25 & 0.02 & 0.27 & 0.04 & -0.33 & 0.93 & 0.56 & 0.69 & 0.90 & 0.45 \\
\hline & & $\mathrm{P}$ & 0.50 & 0.24 & 0.55 & 0.96 & 0.60 & 0.94 & 0.52 & 0.01 & 0.32 & 0.19 & 0.04 & 0.45 \\
\hline
\end{tabular}

of ecosystem responses strengthen, carbon fluxes shift from being controlled mostly by climatic factors to control primarily by ecosystem responses (Richardson et al., 2007; Stoy et al., 2009). Climate is the first to act on ecosystems. Gradually, ecosystem structures and functions (Díaz and Cabido, 1997), such as phenology and species composition (Hooper and Vitousek, 1997), will change, which confounds the relationship between climate and carbon fluxes later stages (Pettorelli et al., 2005). For example, spring phenology was found to exert a major influence on ecosystem carbon balance (Richardson et al., 2009; Richardson et al., 2010), while vegetation type dominated the contribution of ecosystem responses to the IAV (Fig. 5).

\subsection{Factoring out the sources of the inter-annual variability of carbon flux}

To partition the sources of drivers affecting carbon flux IAV, carbon fluxes were computed by three different methods (VC_VER, VC_CER and CC_VER) (Fig. 2 and Table 4). Carbon fluxes computed with the VC_VER were in accord with observed carbon fluxes in each observation year (Fig. 2). Moreover, there was no significant difference of accumulated annual carbon fluxes among the values calculated by VC_VER, VC_CER and CC_VER (Table 4). These findings support the validity of the LUT method employed in this study.

The carbon flux exhibited certain deviations from observed values (VC_VER) when we considered the sole effect of climatic factors (VC_CER) or ecosystem responses (CC_VER) (Fig. 2). In general, carbon fluxes calculated by the CC_VER were similar with those calculated by the VC_VER. However, the inter-annual carbon fluxes calculated by the VC_CER exhibited little change among years, which revealed a higher deviation when estimating carbon fluxes using only climatic factors. Some extreme phenomena might not be captured by the VC_CER method, for example, the higher carbon uptake in 2008 at DX (Figs. 1 (a), 2 (a)).

The IAV results demonstrated the dominant effect of ecosystem responses on carbon fluxes. Among the three approaches, the VC_CER approach resulted in the lowest IAV at all sites (Table 4). The coefficient of variation (CV) generated by the CC_VER method showed a high degree of consistency with the observed carbon fluxes (VC_VER). These two results point to a great proportion of IAV being explained by ecosystem response, and the IAV caused exclusively by climatic factors (VC_CER) was small.

In order to further identify the main source of IAV, we conducted correlation analyses among carbon fluxes calculated by the VC_CER,
CC_VER, and VC_VER approaches (Table 5). For all carbon flux components (NEP, GPP and Re), the CC_VER approach resulted in the highest correlations with site measurements, whereas the VC_CER approach resulted in the lowest correlations. This result provides further evidence that ecosystem response effects dominated the IAV.

\subsection{The relative contributions of climate and ecosystem responses to the IAV of carbon fluxes}

The IAV of carbon fluxes in the three ecosystems as calculated by the approach of VC_VER was smaller than their sum as calculated by CC_VER + VC_CER (Fig. 3). The differences between VC_VER and CC_VER + VC_CER represented the weakening (offset) effect of ecosystem responses on IAV caused by climatic variability, which could buffer and postpone climate effects on ecosystem carbon fluxes (Zhang et al., 2015a). These offset effects were related to ecosystem acclimatization to climate variations (Shao et al., 2014; Richardson et al., 2007; Wohlfahrt et al., 2008b) and ecosystem resistance to disturbance (plasticity of homeostasis) (Odum, 1969; Ogle and Reynolds, 2004; Rodeghiero and Cescatti, 2005). Table 3 reveals that the effects of ecosystem responses were enhanced with time and that the plasticity of homeostasis weakened the climate effects over the entire study period.

The offset effects of ecosystem responses were stronger on GPP IAV than on Re IAV (Fig. 3). This implies that the offset effect on NEP IAV was regulated by the degree of mitigation of ecosystem responses on GPP IAV, which is further supported by a higher correlation between GPP and NEP than that between Re and NEP across the three sites (Fig. 4). Similar findings have been reported for all terrestrial ecosystems in China (Yu et al., 2013) and in related experimental studies (Högberg et al., 2001) and those that conducted parallel measurements of GPP and Re (Larsen et al., 2007). This phenomenon can be related to the fact that GPP, as the main substrate supplier of Re, will inevitably constrain the variation of Re (Yu et al., 2013).

The contribution of ecosystem responses to the IAV varied with vegetation type (Fig. 5). This contribution was greatest for grasslands, followed by shrubs and forests (Hui et al., 2003; Polley et al., 2010; Teklemariam et al., 2010); it was more apparent in deciduous than evergreen forests (Richardson et al., 2007; Wu et al., 2012) and more obvious in alpine meadows than temperate steppes. The contribution of ecosystem responses dependent on vegetation type to the IAV might be related to yearly variations in freshly 


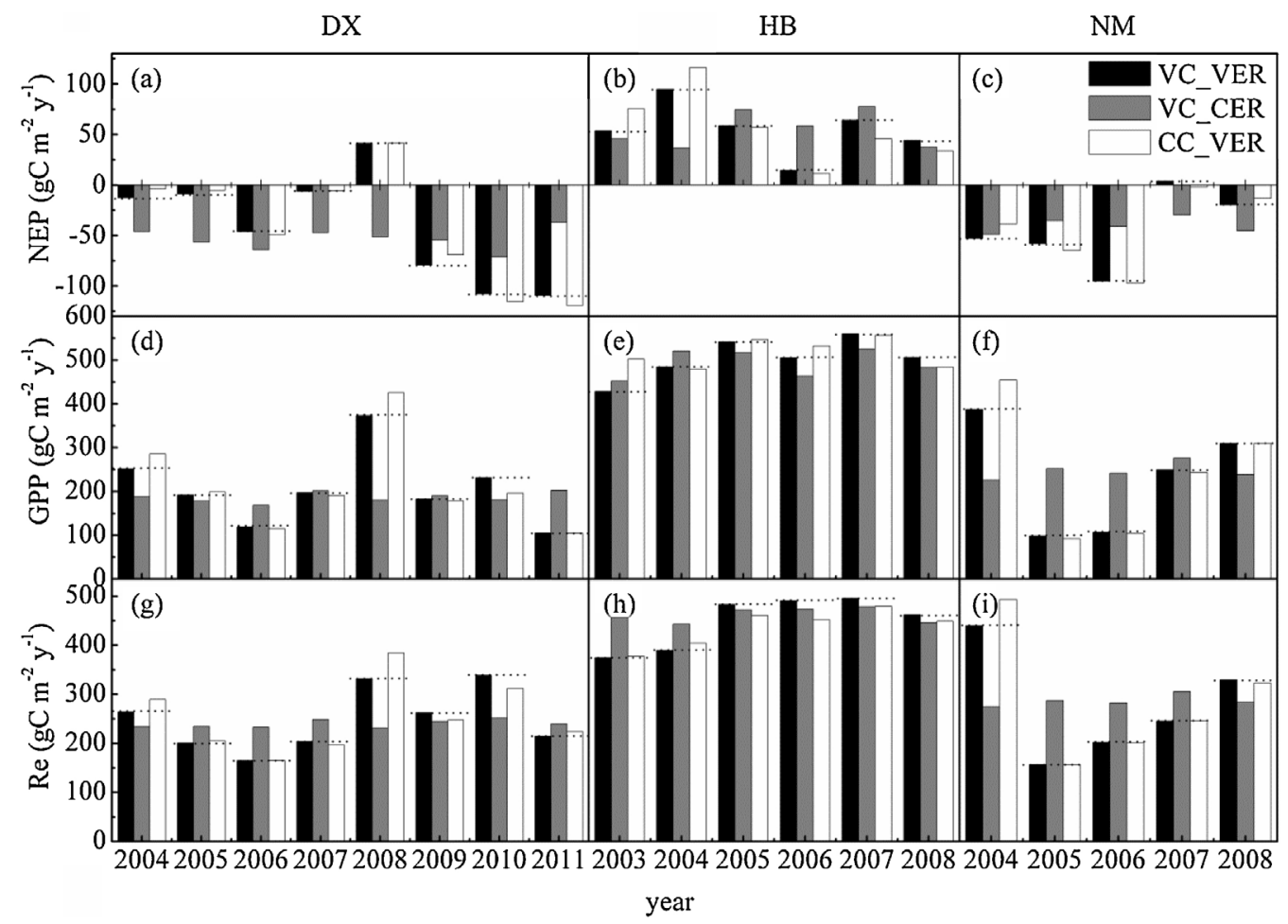

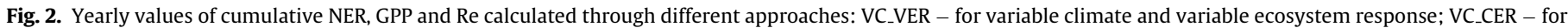
variable climate; CC_VER - for variable ecosystem responses; dashed line - for observed carbon fluxes.

Table 4

Carbon fluxes computed with the three different approaches (VC_VER, VC_CER and CC_VER) for the three sites.

\begin{tabular}{|c|c|c|c|c|c|c|c|c|c|c|}
\hline & & \multicolumn{3}{|c|}{$\operatorname{NEP}\left(\mathrm{gC} \mathrm{m}^{-2}\right.$ year $\left.^{-1}\right)$} & \multicolumn{3}{|c|}{$\operatorname{Re}\left(\mathrm{gC} \mathrm{m}^{-2}\right.$ year $\left.^{-1}\right)$} & \multicolumn{3}{|c|}{$\mathrm{GPP}\left(\mathrm{gC} \mathrm{m}^{-2}\right.$ year $\left.^{-1}\right)$} \\
\hline & & VC_VER & VC_CER & CC_VER & VC_VER & VC_CER & CC_VER & VC_VER & VC_CER & CC_VER \\
\hline \multirow[t]{3}{*}{ DX } & AVG & -41.18 & -53.52 & -40.91 & 247.73 & 239.81 & 252.84 & 206.55 & 186.29 & 211.93 \\
\hline & IAV & 54.08 & 10.72 & 57.62 & 63.21 & 7.71 & 71.89 & 83.87 & 11.86 & 102.71 \\
\hline & $\mathrm{CV}$ & 1.31 & 0.20 & 1.41 & 0.26 & 0.03 & 0.28 & 0.41 & 0.06 & 0.48 \\
\hline \multirow[t]{3}{*}{ HB } & AVG & 55.01 & 55.10 & 56.58 & 449.40 & 461.69 & 436.92 & 504.41 & 493.50 & 516.80 \\
\hline & IAV & 26.25 & 18.19 & 36.36 & 43.58 & 15.05 & 38.41 & 46.20 & 31.55 & 32.72 \\
\hline & $\mathrm{CV}$ & 0.48 & 0.33 & 0.64 & 0.10 & 0.03 & 0.09 & 0.09 & 0.06 & 0.06 \\
\hline \multirow[t]{3}{*}{ NM } & AVG & -44.45 & -40.11 & -43.27 & 274.74 & 286.74 & 283.86 & 230.30 & 246.63 & 240.59 \\
\hline & IAV & 37.95 & 7.67 & 38.66 & 112.15 & 11.55 & 132.19 & 126.26 & 18.83 & 151.22 \\
\hline & $\mathrm{CV}$ & 0.85 & 0.19 & 0.89 & 0.41 & 0.04 & 0.47 & 0.55 & 0.08 & 0.63 \\
\hline
\end{tabular}

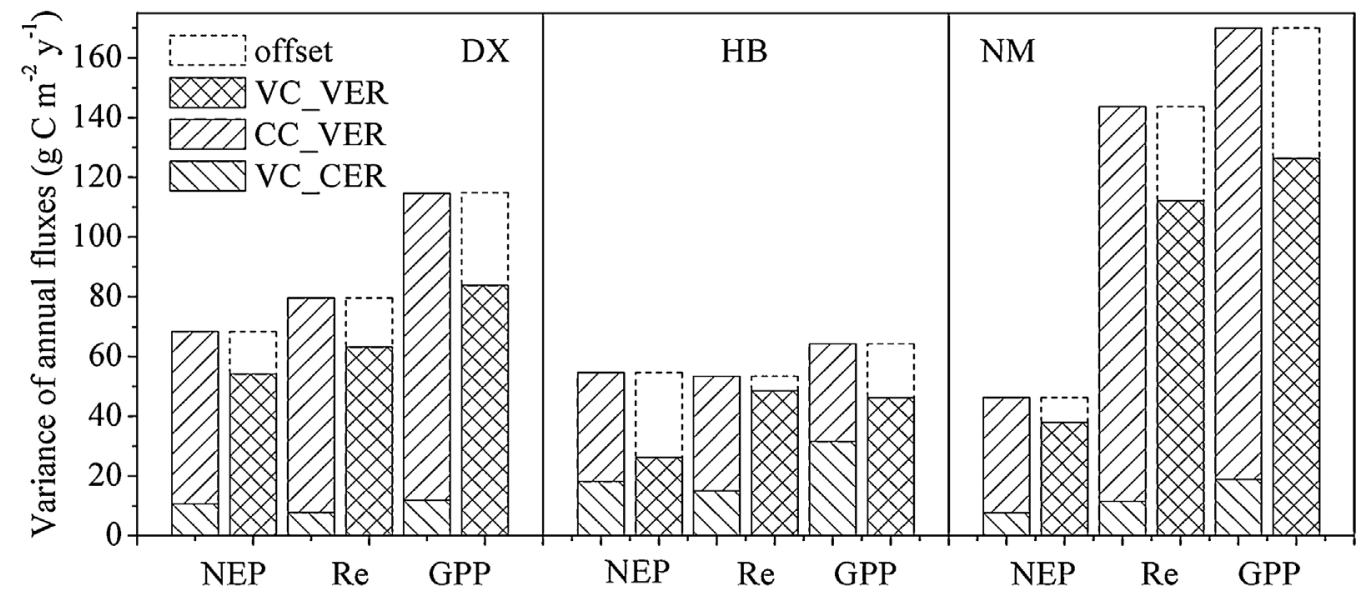

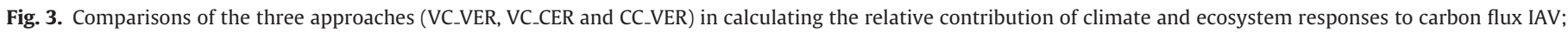
offset is used to indicate the degree of ecosystem responses weakening the effects of climatic variability on carbon fluxes. 

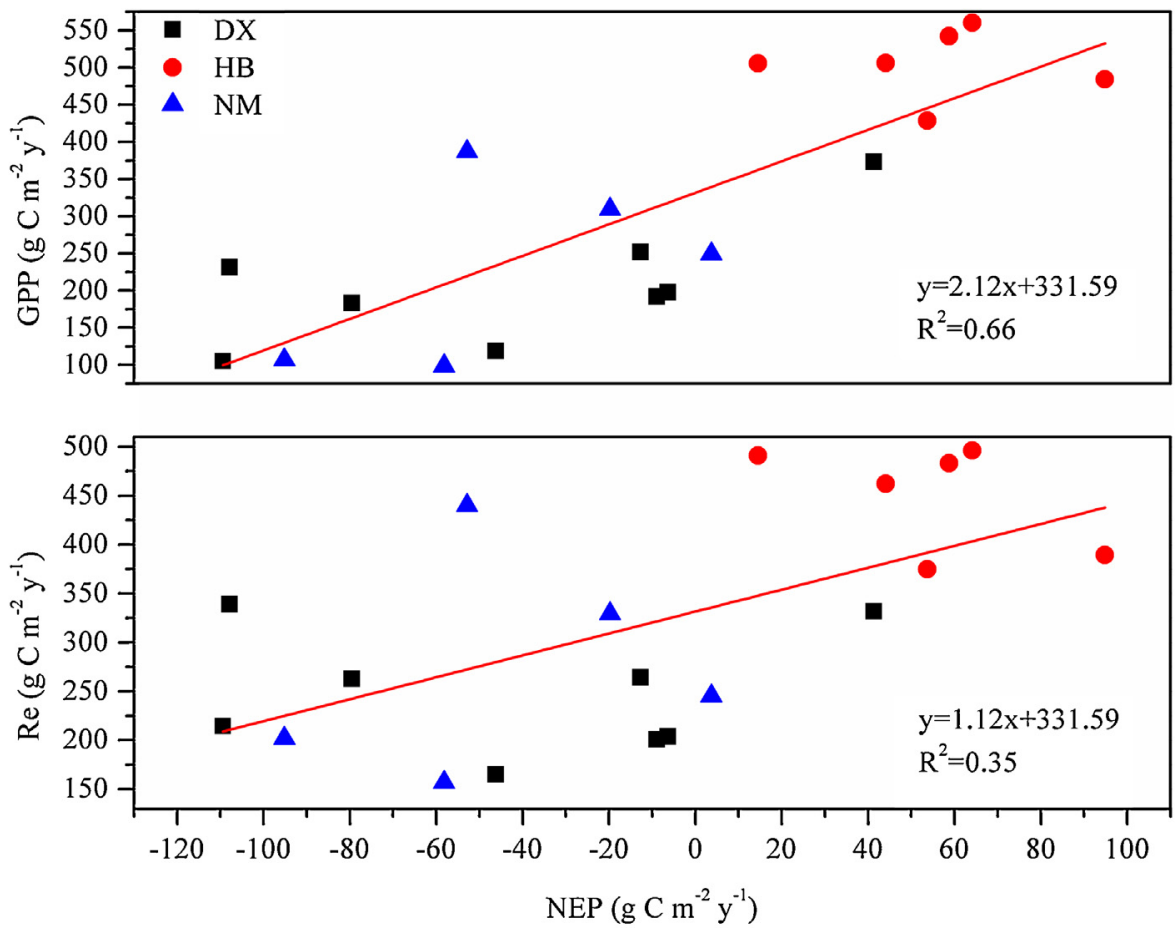

Fig. 4. Relationships between NEP and GPP, Re across the three sites in 2004-2011 at DX, 2003-2008 at HB and 2004-2008 at NM.

Table 5

Correlation coefficients among carbon fluxes calculated from VC_CER, CC_VER approach and VC_VER approaches.

\begin{tabular}{|c|c|c|c|c|c|c|c|}
\hline & & \multicolumn{2}{|c|}{$\mathrm{NEP}\left(\mathrm{gC} \mathrm{m}^{-2}\right.$ year $\left.^{-1}\right)$} & \multicolumn{2}{|c|}{$\operatorname{Re}\left(\mathrm{gCm}^{-2}\right.$ year $\left.^{-1}\right)$} & \multicolumn{2}{|c|}{$\mathrm{GPP}\left(\mathrm{gC} \mathrm{m}^{-2}\right.$ year $\left.^{-1}\right)$} \\
\hline & & VC_CER & CC_VER & VC_CER & CC_VER & VC_CER & CC_VER \\
\hline $\mathrm{DX}$ & VC_VER & 0.16 & $0.99^{\mathrm{b}}$ & 0.22 & $0.94^{\mathrm{b}}$ & -0.19 & $0.98^{\mathrm{b}}$ \\
\hline HB & & -0.17 & $0.91^{\mathrm{a}}$ & 0.73 & $0.97^{\mathrm{b}}$ & 0.68 & 0.71 \\
\hline NM & & 0.37 & $0.97^{b}$ & -0.48 & $0.99^{\mathrm{b}}$ & -0.36 & $0.99^{\mathrm{b}}$ \\
\hline
\end{tabular}

a indicates that the correlation is significant at the 0.05 level.

$\mathrm{b}$ indicates that the correlation is significant at the 0.01 level.

grown above-ground biomass (Adkinson et al., 2011). For example, perennial shrubs account for a high proportion at $\mathrm{HB}$, where the above-ground biomass buildup each year is less than that at DX and NM. As a result, the proportion of IAV caused by ecosystem responses at $\mathrm{HB}$ was smaller than that at DX and NM.

The rate of contribution of ecosystem responses to the IAV remained consistent with elevation, mean annual temperature and precipitation (Fig. 5), which reconfirmed that IAV was dominated by ecosystem responses, not environmental factors. However, environmental factors can indirectly affect the contributions of ecosystem responses to the IAV by regulating vegetation community traits, including species composition, vegetation cover, canopy height, and so on. For example, canopy traits of the Leymus chinesis steppe at NM, the Kobresia pygmaea meadow-steppe at DX, and the Potentilla fruticosa shrub-meadow at HB were different under distinct environment conditions (Table 1 ).

\subsection{Implications of this study for ecosystem modelling}

Currently, parametric models are driven primarily by climate, with few devoting attention to ecosystem response, which usually leads to overestimated simulation results in abnormal climatic years (Griffis and Rouse, 2001), since extreme weather conditions cause stronger ecosystem response, increasing its contribution to the IAV (Reichstein et al., 2013). Therefore, longer-term observations are required to incorporate ecosystem responses and to develop a solid understanding of the correlation between climatic variations and carbon fluxes (Hui et al., 2003; Gunderson et al., 2010).

This study emphasizes the need to incorporate ecosystem responses into parametric models that are solely driven by meteorological factors. When comparing the linkages between ecosystem dynamics and climate among various time periods, effects of ecosystem responses need to be considered. Parameters related to ecosystem responses, such as phenology, ecosystem traits and nutrient cycles, are difficult to incorporate individually. It is better to integrate all biotic factors into one coefficient - an ecosystem response coefficient. This facilitates its incorporation into parametric models. Furthermore, such questions as to how ecosystem responses perform under different climatic conditions, at different time scales, and in different types of ecosystems, and regarding how site scale findings can be up-scaled to larger spatiotemporal scales, need to be further explored in future studies.

\section{Conclusions}

(1) In this study, we separated the two sources of carbon flux IAV using LUTs method in order to quantify the contribution of climatic factors and ecosystem responses to IAV. Results highlight the necessity of incorporating ecosystem responses into those parametric models driven exclusively by meteorological fac- 


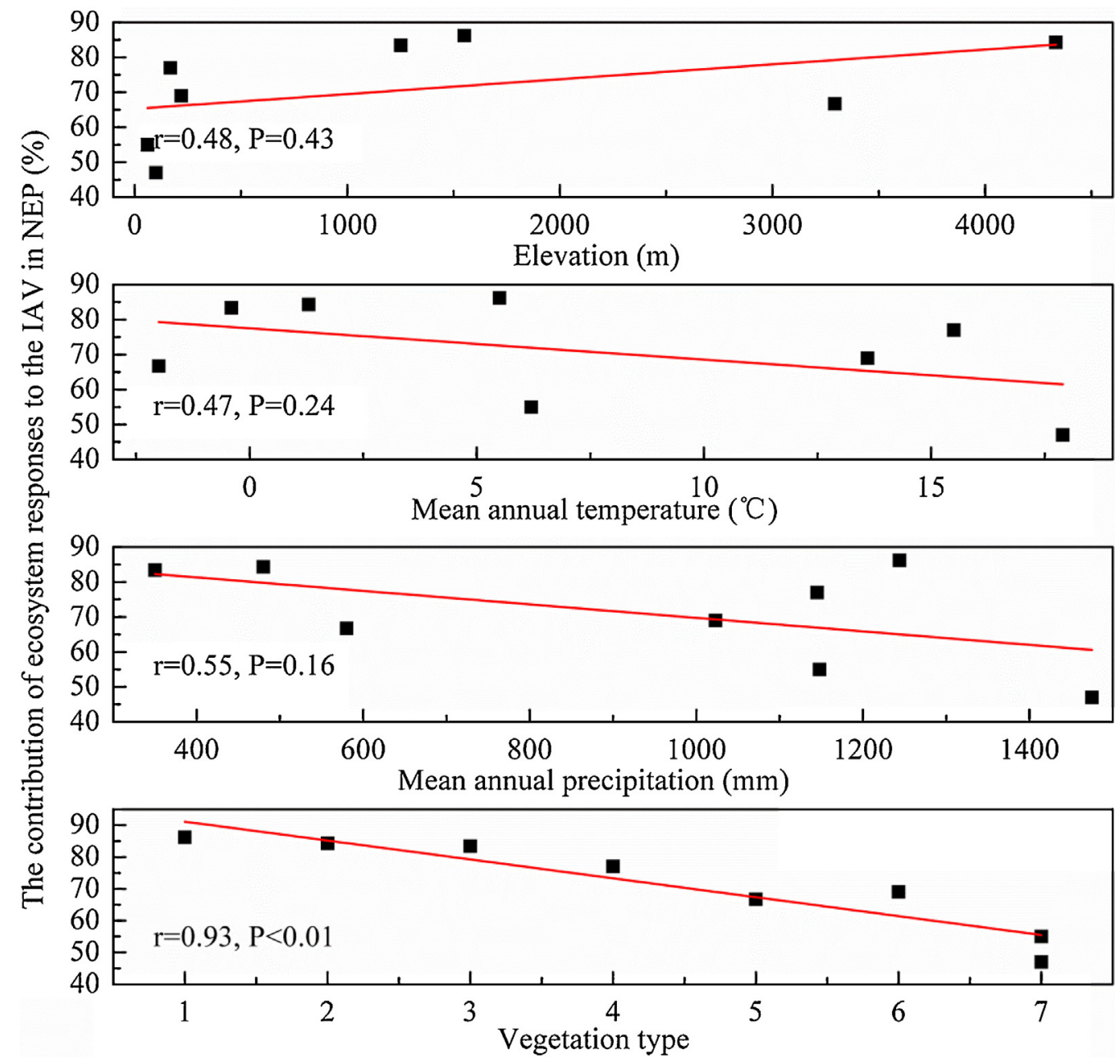

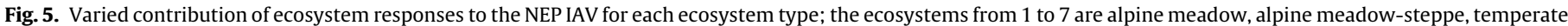

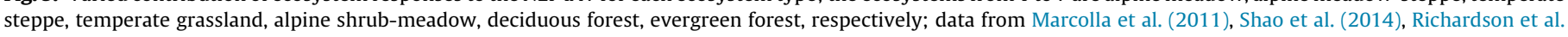
(2007) and this research.

tors, in the process advancing the development of parametric models.

(2) The maximum IAV of GPP and Re both occurred in the peak growing season, whereas the IAV of NEP peaked in the early growing season due to the effects of ecosystem responses. Such responses played a more important role in driving carbon flux IAV than did climate. In addition, the ecosystem responses exerted obvious offset effects on carbon flux IAV caused by climatic variations.

\section{Acknowledgements}

This work was supported by the 973 Program (2013CB956302) of the Ministry of Science and Technology of China, the Strategy Pioneering Program of the Chinese Academy of Sciences (XDA05050404), National Natural Science Foundation of China $(41571195,31500360)$, and China Postdoctoral Science Foundation (2015M581161). We thank the Data Center of Chinese Terrestrial Ecosystem Flux Observation and Research Network (ChinaFLUX) and the Data Center of Chinese Ecosystem Research Network (CERN) for the support of data for this study. Many thanks Yongtao He for making his flux datasets available to us. We also thank Xianjin Zhu, Jian Tao, Yanbin Jiang, Ke Huang and Yaojie Liu for their valuable comments and suggestions.

\section{Appendix A. Supplementary data}

Supplementary data associated with this article can be found, in the online version, at http://dx.doi.org/10.1016/j.agrformet.2016. 05.004 .

\section{References}

Adkinson, A.C., Syed, K.H., Flanagan, L.B., 2011. Contrasting responses of growing season ecosystem $\mathrm{CO}_{2}$ exchange to variation in temperature and water table depth in two peatlands in northern Alberta, Canada. J. Geophys. Res. 116, G01004.

Barford, C.C., et al., 2001. Factors controlling long- and short-term sequestration of atmospheric $\mathrm{CO}_{2}$ in a mid-latitude forest. Science 294, 1688-1691.

Barron-Gafford, G.A., Scott, R.L., Jenerette, G.D., Hamerlynck, E.P., Huxman, T.E., 2012. Temperature and precipitation controls over leaf- and ecosystem-level $\mathrm{CO}_{2}$ flux along a woody plant encroachment gradient. Global Change Biol. 18 1389-1400.

Berendse, F., et al., 2001. Raised atmospheric $\mathrm{CO}_{2}$ levels and increased $\mathrm{N}$ deposition cause shifts in plant species composition and production in Sphagnum bogs. Global Change Biol. 7, 591-598.

Botta, A., Viovy, N., Ciais, P., Friedlingstein, P., Monfray, P., 2000. A global prognostic scheme of leaf onset using satellite data. Global Change Biol. 6, 709-725.

Braswell, B.H., Schimel, D.S., Linder, E., Moore, B., 1997. The response of global terrestrial ecosystems to interannual temperature variability. Science 278 , $870-872$.

Burba, G.G., McDermitt, D.K., Grelle, A., Anderson, D.J., Xu, L.K., 2008. Addressing the influence of instrument surface heat exchange on the measurements of $\mathrm{CO}_{2}$ flux from open-path gas analyzers. Global Change Biol. 14, 1854-1876.

Díaz, S., Cabido, M., 1997. Plant functional types and ecosystem function in relation to global change. J. Veg. Sci. 8, 463-474. 
Desai, A.R., Helliker, B.R., Moorcroft, P.R., Andrews, A.E., Berry, J.A., 2010. Climatic controls of interannual variability in regional carbon fluxes from top-down and bottom-up perspectives. J. Geophys. Res. 115, http://dx.doi.org/10.1029/ 2009jg001122 (G02011).

Falge, E., et al., 2001. Gap filling strategies for defensible annual sums of net ecosystem exchange. Agric. For. Meteorol. 107, 43-69.

Flanagan, L.B., Wever, L.A., Carlson, P.J., 2002. Seasonal and interannual variation in carbon dioxide exchange and carbon balance in a northern temperate grassland. Global Change Biol. 8, 599-615.

$\mathrm{Fu}$, Y.L., et al., 2006a. Depression of net ecosystem $\mathrm{CO}_{2}$ exchange in semi-arid Leymus chinensis steppe and alpine shrub. Agric. For. Meteorol. 137, 234-244.

Fu, Y.L., Yu, G.R., Wang, Y.F., Li, Z.Q., Hao, Y.B., 2006b. Effect of water stress on ecosystem photosynthesis and respiration of a Leymus chinensis steppe in Inner Mongolia. Sci. China Ser. D 49, 196-206.

Gilmanov, T.G., et al., 2007. Partitioning European grassland net ecosystem $\mathrm{CO}_{2}$ exchange into gross primary productivity and ecosystem respiration using light response function analysis. Agric. Ecosyst. Environ. 121, 93-120.

Goetz, S.J., Mack, M.C., Gurney, K.R., Randerson, J.T., Houghton, R.A., 2007. Ecosystem responses to recent climate change and fire disturbance at northern high latitudes: observations and model results contrasting northern Eurasia and North America. Environ. Res. Lett. 2, 045031.

Granier, A., et al., 2007. Evidence for soil water control on carbon and water dynamics in european forests during the extremely dry year: 2003. Agric. For. Meteorol. 143, 123-145.

Griffis, T.J., Rouse, W.R., 2001. Modelling the interannual variability of net ecosystem $\mathrm{CO}_{2}$ exchange at a subarctic sedge fen. Global Change Biol. 7, 511-530.

Griffis, T.J., Rouse, W.R., Waddington, J.M., 2000. Interannual variability of net ecosystem $\mathrm{CO}_{2}$ exchange at a subarctic fen. Global Biogeochem. Cycles 14 1109-1121.

Gunderson, C.A., O’Hara, K.H., Campion, C.M., Walker, A.V., Edwards, N.T., 2010. Thermal plasticity of photosynthesis: the role of acclimation in forest responses to a warming climate. Global Change Biol. 16, 2272-2286.

Högberg, P., et al., 2001. Large-scale forest girdling shows that current photosynthesis drives soil respiration. Nature 411, 789-792.

Hao, Y.B., et al., 2006. Seasonal variation in carbon exchange and its ecological analysis over Leymus chinensis steppe in inner Mongolia. Sci. China Ser. D 49, $186-195$.

Hao, Y.B., et al., 2008. $\mathrm{CO}_{2}: \mathrm{H}_{2} \mathrm{O}$ and energy exchange of an inner mongolia steppe ecosystem during a dry and wet year. Acta Oecol. 33, 133-143.

Hollinger, D.Y., et al., 2004. Spatial and temporal variability in forest-atmosphere $\mathrm{CO}_{2}$ exchange. Global Change Biol. 10, 1689-1706.

Hooper, D.U., Vitousek, P.M., 1997. The effects of plant composition and diversity on ecosystem processes. Science 277, 1302-1305.

Hui, D., Luo, Y., Katul, G., 2003. Partitioning interannual variability in net ecosystem exchange between climatic variability and functional change. Tree Physiol. 23, 433-442.

Katul, G., et al., 2001. Multiscale analysis of vegetation surface fluxes: from seconds to years. Adv. Water Res. 24, 1119-1132.

Larsen, K.S., Ibrom, A., Jonasson, S., Michelsen, A., Beier, C., 2007. Significance of cold-season respiration and photosynthesis in a subarctic heath ecosystem in Northern Sweden. Global Change Biol. 13, 1498-1508.

Li, Y., et al., 2003. The comparison of community biomass and environmental condition of five vegetational type in alpine meadow of haibei, qinghai province. J. Mt. Sci. Engl. 21, 257-264.

Marcolla, B., et al., 2011. Climatic controls and ecosystem responses drive the inter-annual variability of the net ecosystem exchange of an alpine meadow. Agric. For. Meteorol. 151, 1233-1243.

Misson, L., et al., 2010. Functional changes in the control of carbon fluxes after 3 years of increased drought in a Mediterranean evergreen forest? Global Change Biol. 16, 2461-2475.

Novick, K.A., et al., 2004. Carbon dioxide and water vapor exchange in a warm temperate grassland. Oecologia 138, 259-274.

Odum, E.P., 1969. Strategy of ecosystem development. Science 164, 262-270.

Ogle, K., Reynolds, J.F., 2004. Plant responses to precipitation in desert ecosystems: integrating functional types, pulses, thresholds, and delays. Oecologia 141, 282-294.

Parton, W., et al., 2012. Impact of precipitation dynamics on net ecosystem productivity. Global Change Biol. 18, 915-927.

Pettorelli, N., et al., 2005. Using the satellite-derived NDVI to assess ecological responses to environmental change. Trends Ecol. Evol. 20, 503-510.

Piao, S.L., et al., 2008. Net carbon dioxide losses of northern ecosystems in response to autumn warming. Nature $451,49-53$.

Polley, H.W., et al., 2010. Physiological and environmental regulation of interannual variability in $\mathrm{CO}_{2}$ exchange on rangelands in the western United States. Global Change Biol. 16, 990-1002.

Potter, C., et al., 2001. Modeling seasonal and interannual variability in ecosystem carbon cycling for the Brazilian Amazon region. J. Geophys. Res. 106, 10423-10446.

Reichstein, M., et al., 2005. On the separation of net ecosystem exchange into assimilation and ecosystem respiration: review and improved algorithm. Global Change Biol. 11, 1424-1439.

Reichstein, M., et al., 2013. Climate extremes and the carbon cycle. Nature 500, 287-295.
Reverter, B.R., et al., 2011. Adjustment of annual NEE and ET for the open-path IRGA self-heating correction: magnitude and approximation over a range of climate. Agric. For. Meteorol. 151, 1856-1861.

Richardson, A.D., Hollinger, D.Y., Aber, J.D., Ollinger, S.V., Braswell, B.H., 2007. Environmental variation is directly responsible for short-but not long-term variation in forest-atmosphere carbon exchange. Global Change Biol. 13, 788-803.

Richardson, A.D., et al., 2009. Influence of spring phenology on seasonal and annual carbon balance in two contrasting New England forests. Tree Physiol. 29, 321-331.

Richardson, A.D., et al., 2010. Influence of spring and autumn phenological transitions on forest ecosystem productivity. Philos. Trans. R. Soc. Lond. Ser. B 365, 3227-3246.

Rodeghiero, M., Cescatti, A., 2005. Main determinants of forest soil respiration along an elevation/temperature gradient in the Italian Alps. Global Change Biol. 11, 1024-1041.

Rustad, L., et al., 2001. A meta-analysis of the response of soil respiration, net nitrogen mineralization, and aboveground plant growth to experimental ecosystem warming. Oecologia 126, 543-562.

Schimel, D.S., et al., 2001. Recent patterns and mechanisms of carbon exchange by terrestrial ecosystems. Nature 414, 169-172.

Shao, C., Chen, J., Li, L., 2013. Grazing alters the biophysical regulation of carbon fluxes in a desert steppe. Environ. Res. Lett. 8, 025012.

Shao, J., et al., 2014. Partitioning climatic and biotic effects on interannual variability of ecosystem carbon exchange in three ecosystems. Ecosystems 17, $1186-1201$.

Shao, J., et al., 2015. Biotic and climatic controls on interannual variability in carbon fluxes across terrestrial ecosystems. Agric. For. Meteorol. 205, 11-22.

Shi, P.L., et al., 2006. Net ecosystem $\mathrm{CO}_{2}$ exchange and controlling factors in a steppe - Kobresia meadow on the Tibetan Plateau. Sci. China Ser. D 49, 207-218.

Song, Y.Y., Simard, S.W., Carroll, A., Mohn, W.W., Zeng, R.S., 2015. Defoliation of interior Douglas-fir elicits carbon transfer and stress signalling to ponderosa pine neighbors through ectomycorrhizal networks. Sci. Rep. UK 5, 8495.

Stevens, C.J., Dise, N.B., Mountford, J.O., Gowing, D.J., 2004. Impact of nitrogen deposition on the species richness of grasslands. Science 303, 1876-1879.

Stoy, P.C., et al., 2009. Biosphere-atmosphere exchange of $\mathrm{CO}_{2}$ in relation to climate: a cross-biome analysis across multiple time scales. Biogeosciences 6, 2297-2312.

Suyker, A.E., Verma, S.B., Burba, G.G., 2003. Interannual variability in net $\mathrm{CO}_{2}$ exchange of a native tallgrass prairie. Global Change Biol. 9, 255-265.

Teklemariam, T.A., Lafleur, P.M., Moore, T.R., Roulet, N.T., Humphreys, E.R., 2010. The direct and indirect effects of inter-annual meteorological variability on ecosystem carbon dioxide exchange at a temperate ombrotrophic bog. Agric. For. Meteorol. 150, 1402-1411.

Webb, E.K., Pearman, G.L., Leuning, R., 1980. Correction of flux measurement for density effects due to heat and water vapor transfer. Q. J. R. Meteorol. Soc. 106 $85-100$.

Wen, X.F., et al., 2006. Soil moisture effect on the temperature dependence of ecosystem respiration in a subtropical Pinus plantation of southeastern China. Agric. For. Meteorol. 137, 166-175.

Wilczak, J.M., Oncley, S.P., Stage, S.A., 2001. Sonic anemometer tilt correction algorithms. Boundary Layer Meteorol. 99, 127-150.

Wohlfahrt, G., et al., 2008a. Biotic, abiotic, and management controls on the net ecosystem $\mathrm{CO}_{2}$ exchange of european mountain grassland ecosystems. Ecosystems 11, 1338-1351.

Wohlfahrt, G., et al., 2008b. Seasonal and inter-annual variability of the net ecosystem $\mathrm{CO}_{2}$ exchange of a temperate mountain grassland: effects of weather and management. J. Geophys. Res. 113, D08110.

Wu, W.X., et al., 2008. Modeling gross primary production of a temperate grassland ecosystem in Inner Mongolia, China, using MODIS imagery and climate data. Sci. China Ser. D 10, 1501-1512.

Wu, J., et al., 2012. Effects of climate variability and functional changes on the interannual variation of the carbon balance in a temperate deciduous forest. Biogeosciences 9, 13-28.

Xu, L.K., Baldocchi, D.D., 2004. Seasonal variation in carbon dioxide exchange over a Mediterranean annual grassland in California. Agric. For. Meteorol. 123, 79-96.

Xu, M., et al., 2014. Effects of climatic factors and ecosystem responses on the inter-annual variability of evapotranspiration in a coniferous plantation in subtropical China. PLoS One 9, e85593.

Yu, G.R., et al., 2013. Spatial patterns and climate drivers of carbon fluxes in terrestrial ecosystems of China. Global Change Biol. 19, 798-810.

Zhang, W.J., et al., 2011. Underestimated effects of low temperature during early growing season on carbon sequestration of a subtropical coniferous plantation. Biogeosciences 8, 1667-11678.

Zhang, T., et al., 2015a. Lagged climatic effects on carbon fluxes over three grassland ecosystems in China. J. Plant Ecol. UK. 8, 291-302.

Zhang, T., et al., 2015b. Light-intensity grazing improves alpine meadow productivity and adaption to climate change on the Tibetan Plateau. Sci. Rep. UK 5, 15949, http://dx.doi.org/10.1038/srep15949.

Zhu, X.J., et al., 2012. Instrument heating correction effect on estimation of ecosystem carbon and water fluxes. Chin. J. Ecol. 31, 487-493. 